\title{
Model of Indigenous Community Participation in Tackling Illegal Fishing in the Selaru Island Waters of West Southeast Maluku
}

\author{
Riska Andi Fitriono ${ }^{1}$, Barda Nawawi Arief $^{2}$, FX Adji Samekto ${ }^{3}$ \\ $1,2,3$ Doctor of Law Science Program Universitas Diponegoro, Semarang - Indonesia \\ rizka.andi86@gmail.com
}

\begin{abstract}
LIPI Oceanographic Research Center reveals that only $35 \%$ of Indonesia's coral reefs are classified as very good. While $27.18 \%$ were classified in good condition, $37.25 \%$ were in adequate condition, and $30.45 \%$ were in bad condition. the last half century of coral reef degradation in Indonesia increased from $10 \%$ to $50 \%$. Even some fisheries areas in Indonesia already face symptoms of overfishing for several important commodity groups, such as large pelagic, small pelagic, shrimp, and demersal fish. Ironically, small fishermen who feel the impact of the threat of scarcity of fisheries. This research is a study using the socio legal research approach. Socio legal research approach means that there are two aspects of research. First, legal research aspects, and second, socio research. The Indigenous Community Participation Model in Tackling Illegal Fishing in the Selaru Island of West Southeast Maluku namely through the sasi customary law model, Sasi Laut only applies to superior strategic commodities of the sea that have high economic value. Thus, the community is free to engage in fishing activities in the Sasi Sea region by the requirement not to use fishing gear that damages sea areas such as fish bombs, cyanide, and fish (electric) stingers. In upholding illegal fishing through customary sasi law, indigenous peoples have a very important role in upholding the implementation of sea sasi, indigenous peoples form customary institutions, namely 1) through the church, 2) Customary parties, in this case represented by soa petuanan authority holders at sea, and 3) Village government.
\end{abstract}

Keywords: Indigenous Peoples, Illegal Fishing.

\section{INTRODUCTION}

Indonesian territory is a sea area sprinkled with islands, both large and small with a total of around 17,504 islands. The total area of Indonesia is an archipelago (archipelagic state) tert ebut is approximately 7.7 million $\mathrm{km}^{2}$. Two thirds of the total area of 5.8 million $\mathrm{Km}^{2}$ are oceans which contain abundant potential marine resources and have very strategic value for the national life of the Indonesian people. With a coastline of more than $81,000 \mathrm{Km}$, Indonesia has the second longest island in the world after Canada . [1]

The Indonesian archipelago spans between the Indian Ocean and Pacific Ocean in Indonesia reaching 50,875 square kilometers, [2] or about $18 \%$ of the total area of the world's coral reefs. Most of the coral reefs are located in parts of eastern Indonesia, in the area commonly known as the triangle of coral (coral triangle ).

In addition to bringing economic benefits, the coral reef ecosystem protects the coast from the waves, thus reducing abrasion and damage. Coral reefs also contribute to the fishing sector by providing spawning and nurturing areas, providing food and shelter for various types of marine creatures.

The LIPI Oceanographic Research Center revealed that only $35 \%$ of Indonesia's coral reefs are classified as very good. While $27.18 \%$ were classified as good, $37.25 \%$ were in good condition, and $30.45 \%$ were in bad condition 11 . the last half century of coral reef degradation in Indonesia increased from $10 \%$ to $50 \%$. [3]

Even some fisheries areas in Indonesia already face symptoms of overfishing for several important commodity groups, such as large pelagic, small pelagic, shrimp, and demersal fish. Ironically, small fishermen who feel the impact of the threat of scarcity of fisheries. Imagine, they have to pay more for the fuel component (fuel oil), because the location of fishing (fishing ground) is increasingly distant. The majority of fishing gear are in Sulawesi and Maluku-Papua. Gill nets are used in all areas. Even though large-scale fishing gear is only $10 \%$, its existence cannot be denied due to overfishing. The larger the fishing gear, the greater the catch volume.

Another threat is mining in coastal areas and small islands. Mining activities from quarrying to processing result in damage and pollution to the surrounding coastal ecosystems and biological resources. For this reason, the need for the use and management of natural resources in the national interest is expected to provide opportunities for the customary law community to implement the rights of indigenous peoples, which are regulated in legal recognition, showing positive things in improving people's welfare and ecological sustainability.

Customary / local legal communities have a strategic role in managing coastal and marine resources. Customary / local legal communities are identical with high dependence on natural resources in their areas so that they tend to endeavor to manage natural resources in a sustainable and sustainable manner. Sustainable management of natural resources is reflected in the philosophy of their lives which always maintains a balance of human relations with nature. The practice of management of coastal resources based on indigenous peoples or local wisdom grows from generation to generation, including the commander of laot, sasi, awigawig, seke, malombo, romping, pele-pele-pele, pelamba, 
and kelong. However, some local wisdom in an area is still original, some results of revitalization, and some are starting to fade. [4] Indigenous peoples will try to preserve the environment because it is directly related to their livelihood systems and their food security systems.

The principle of returning to nature is currently also being recognized as one of the concerns of scientists, governments, businesses, and other stakeholders in the management of natural resources. Thus, indigenous / local communities have a very strong contribution because these principles are very closely related to the values they uphold in everyday life. world fisheries experts have also begun to look at community-based management models. Experts realize that science also has limitations that should be supplemented by local knowledge of fishermen . [5]

This is like in the model of community-based management of the marine sasi island in Selaru, West Southeast Maluku, namely through bottom-up planning with a participatory approach so as to increase the fallout of customary / local rules. The Selaru Island community has very diverse cultures and traditions, ranging from traditional dances, fabric weaving skills, maritime culture in the design of wooden ships, sea sasi traditions and land sasi in managing marine and agricultural / plantation resources, and social traditions others are like the village reception tradition. The above traditions and culture can be found in almost all villages in Selaru Island.

The production and sales value of capture fisheries commodities in Selaru Island have continued to increase in the last three years. In 2012 the total fishery production in Selaru Island was 907.97 tons with a sales value of $\mathrm{Rp} 12.13$ billion. This amount of fishery production increased to $1,011.89$ tons with a sales value of $\mathrm{Rp} 13.18$ billion in 2014. Growth in production and sales value of capture fisheries commodities in Selaru Island shows that the capture fisheries sub-sector has potential utilization that can improve the welfare of the people of Selaru Island.

TABLE 1. PRODUCTION AND VALUE OF CAPTURE FISHERIES IN SELARU DISTRICT 2012-2014 PERIOD

\begin{tabular}{|c|c|c|c|}
\hline No & Year & $\begin{array}{c}\text { Production } \\
\text { (Ton) }\end{array}$ & $\begin{array}{c}\text { Value } \\
\text { (Billion) }\end{array}$ \\
\hline 1 & 2012 & 907,97 & 12,13 \\
\hline 2 & 2013 & 937,96 & 12,52 \\
\hline 3 & 2014 & $1.011,89$ & 13,18 \\
\hline
\end{tabular}

Source: Selaru District in 2015

The influence of fishing technology on the island of Selaru still colors the traditions of the fishing community in managing and utilizing marine areas. In some villages it was determined that the sea area of the village could only be exploited by fishermen with certain fishing technologies. If these areas are exploited by fishermen who use fishing technology that is not in accordance with the local community's customary provisions, then these violators will be subject to adat sanctions. For example, one of the fishermen from Adaut village, interview, 28/10/2015) if there are fishermen who use fishing technology that is not the same as the local fishermen, then the fishermen are considered to violate customary rules and sanctions cannot conduct fishing activities in the area. The prohibition is related to the belief of the fishing community, that there are fish species which, if caught using modern technology, will result in reduced development of the fish habitat. However, this prohibition usually only applies to areas of sea customary rights that are very close to the village or village of a fisherman.

\section{RESEARCH METHOD}

In accordance with the objectives of this legal research, that this research is a study using the socio legal research approach, [6] the socio legal research approach means that there are two aspects of research. First, legal research aspects, namely the object of research remains in the form of law in the sense of norms (legislation) and second, socio research, namely the use of methods and theories of social science about law to assist researchers in conducting analysis.

This approach is used to understand the law in the context of the community. By Brian Z. Tamanaha said that law and society have a frame called The Law Society Framework which has certain relationship characteristics. This relationship is indicated by two basic components. The first component consists of two main themes, namely the idea that states that law is the cerium of society and the idea that the function of law is to maintain social orders. The second component consists of three elements, namely customs / consent; morality / reason; and positive law. [7]

\section{DISCUSSION}

\section{Indigenous Peoples}

In Indonesia, there are various terms that refer to the "indigenous peoples" category. The first term used was the term natives, indigenous people, indigenous peoples, customary law communities, indigenous peoples, isolated tribal communities, remote indigenous communities, and traditional communities. These terms are introduced by various regimes for the purpose of identification, categorization, and in the context of development program interventions. Of these, the term customary law community is the most widely used today, for example in Law Number 5 of 1960 concerning Basic Regulations on Agrarian Principles (LoGA). This term has also been widely adopted in a number of other laws, such as the Forestry Act, the Plantation Law, the Fisheries Act, and the Coastal and Marine Management Law.

According to Fauzi and Siscawati (2014), [8] the term "customary law community" should be understood as an equivalent of "adat rechtsgemeenschap". The term rechtsgemeenschap is translated. from Dutch to "customary law community" is "law society" and "custom". Not "community" and "customary law". However, to facilitate terminology in research activities and programming, the term "indigenous peoples".

Considering that this study places more emphasis on indigenous and tribal peoples in the small island of Selaru, juridically, indigenous peoples who are targeted for empowerment in this study must refer to the understanding of indigenous peoples that have been adopted in the regime of the Coastal and Island Area 
Management Act -small island. In Law Number 27 of 2007 amended by Law Number 1 of 2014 concerning Management of Coastal Areas and Small Islands there is a clear and decisive translation of some important terms in the management of coastal resources and small islands. Article 1 states that what is meant by communities is indigenous peoples, local communities, and traditional communities who live in coastal areas and small islands.

Indigenous communities with all traditional fisheries practices and local wisdom that are still inherent in fisheries management are important things in state policies that are increasingly accommodating to local institutions. In fact, if we setback, the real contents of local wisdom have been discussed and recognized in several international conventions, including those adopted in several fisheries code of ethics. For example, as stipulated in the 1982 UN Convention on the Law of the Sea, the FAO Code of Responsible Fisheries in 1995 by FAO, the 2015 Sustainable Small Scale Fisheries Safety Guidelines by FAO. These international conventions and codes of ethics have been approved by member countries so they have legal implications for adoption in the national legal system (legislation). In the national laws of indigenous peoples and local wisdom related to illegal fishing there is law number 45 of 2009 concerning fisheries, law number 11 of 2014 concerning management of coastal areas and small islands, and law number 32 of 2004 about marine.

2. The Model of Participation of Sasi Indigenous Peoples in Tackling Illegal Fishing in Selaru Island Waters

\section{a. The Tradition of Spiritual Kinship (Duan-Lolat)}

Duan-lolat custom is a spirit of kinship in family and social relations in the Selaru District community, especially Adaut Village. In this traditional relationship, the position of an uncle is the main key to solving problems and conflicts that occur within a clan or small family. An uncle (duan) becomes a protector of a problem / personal / social conflict that befalls a dulat (nephew). Likewise, as high as any social position or structural position in a Mat's bureaucracy, he still must submit and respect a duan.

\section{b. Adat Sitting Traditions}

The tradition of sitting down is a basic philosophy that all problems and conflicts faced by citizens can be resolved by custom. If there is a problem or conflict in the community, the mechanism for solving the problem in Adaut Village is carried out by way of sitting adat. The parties who have a problem or are involved in a conflict will be called to seek a solution to the problem or conflict encountered. The customary sitting procession depends on the level of problem or conflict encountered. The greater the problem / conflict faced, the wider the parties involved in the customary sitting procession. This process is usually carried out if there are problems in the internal village such as the problem of elopement, fights between citizens, household conflicts, and others.

\section{c. Customary Rites Close and Open Sasi Land and Sea} Sasi

Sasi's local wisdom on Selaru Island, both sasi land and sea sasi, has become a culture that is closely related to people's lives. Sasi laut and sasi terarat are carried out with a number of traditional rituals led by traditional leaders from certain soas. Every village on Selaru Island has almost the same sasi ritual. A detailed explanation of the closed and open sasi traditional ritual is explained in Section 2.3 .

\section{d. Maritime Culture}

The maritime culture of the Selaru Island community is quite high. The Selaru Island community has the knowledge and culture of building large vessels for shipping or fisheries, especially in Adaut Village. Shipping engineers (called shipbuilders) can design and build ships up to 50 meters long and 8 meters wide. This knowledge was passed down from generation to generation by their parents only by observing the work of the ship's predecessor. Ships built by ship builders in Adaut Village are generally orders from Adaut residents and villagers in Selaru District.

There is a traditional ceremony for releasing ships to the sea. In this ceremony the women of the ship owner will contribute various types of food and the need to release the ship from land to sea. All members of the Adaut community, both children and adults, both men and women, will be invited by the ship owner to come to the ship release ceremony to the sea. The release of the ship to the sea will be led by a traditional leader conducted at low tide. After releasing the ship, all residents will be given food by the ship owner and eat together along the beach.

\section{e. Institutional Management of Marine Sasi}

Almost all villages on Selaru Island have the local wisdom of the sea and sasz 'land. Sea Sasi is generally applied to maintain and regulate the use of higheconomic value fishery resources, such as lola, sea cucumbers, pearl oysters, and lobsters. Sea Sasi is not applied to all types of fish so that fishermen on Selaru Island can still utilize fish resources in the Sea Sasi region as long as sea Sasi is implemented or known as "Sea Sasi Cover". In depth, the marine sasi institutional profile in Adaut Village was used as a representation of the sea sasi implementation on Selaru Island.

The following is an institutional analysis of marine sasi management on Selaru Island with reference to the elements that determine the success of community-based resource management: First, Borderline. Sea Sasi in Adaut Village and generally in other villages on Selaru Island do not have clear boundaries set forth in a village map. Sasi Laut in Adaut Village is divided into two zones. First, the shallow sea sasi, the tidal area drawn from the coastline to the 400 meter boundary of the coastline. Sasi shallow sea is generally up to 15 meters deep sea. The people of Adaut Village are still able to dive to a depth of 14 meters to take sea cucumbers and lola without breathing apparatus. Second, deep sea sasi, which is an area of water from a depth of 15 meters (400 meters from the coast) to the free sea. Second, Authority. The authority of sea sasi and land sasi are on the three organizers and public services in Adaut Village, in tackling illegal fishing, namely the church, traditional institutions, and village government. The description of the authority of each institution is explained as follows:

1) The church performs a procession of blessing at the church and conducts outreach to the 
congregation during worship. The church will also notify the congregation when the time of sea serving will be opened.

2) Customary parties, in this case, are represented by soa holders of petuan authority at sea coordinate and determine the closing time and open sea sasi. The adat party was also involved in the procession of the closing ceremony and opening of the sea sasi on the beach.

3) The village government enforces rules, imposes sanctions, and supervises seated sea custody areas.

Third, the rules. Sea Sasi regulations in Adaut Village are still verbal. The rules of sea sasi consist of the rules of customary processions for closing and opening sea sasi, rules containing prohibitions, and sanctions imposed on violators of sea sasi. The customary procession to close and open the sea sasi is done in stages with the following sequence:

1) All questions will gather to discuss the preparation of the sea sasi cover at Ngri Mase Village Hall.

2) After the meeting is finished, the questions which have authority in the sea escapades, namely Onjout, Nifmase, and Nuslare, will return to their respective questions to discuss the customs of the sea sasi ritual.

3) On the appointed day, the traditional elders will head to the beach to perform the ritual of closing / opening sea sasi.

Fourth, Penalty. Sanctions for marine offenders are divided into two categories, namely spiritual sanctions and physical sanctions. Spiritual sanctions are mystical sanctions. The community believes that anyone who violates the rules of the sea sasi will be condemned by the village's ancestors and will be struck down by disaster, such as illness, even death. These sanctions are strongly upheld and most feared by the public. While physical sanctions are sanctions that will be given to violators in the form of 25 rattan blows to the body (from the waist to the thigh).

Physical sanctions are imposed by village government officials with a very hard rattan blow to provide a deterrent effect to violators of sea sasi. Next is the sanction of a fine, namely the village government will confiscate all sea products stolen by violators of the sea sasi, then required to submit fines decided by traditional leaders and the village government based on the type of violation. Penalties usually involve paying a sum of money to the village treasury. Along with the development of human rights, sanctions in the form of physical punishment began to be stopped from the rules of sanctions in the last five years.

\section{IV.CONCLUSION}

The Indigenous Community Participation Model in Tackling Illegal Fishing in the Selaru Island of West Southeast Maluku namely through the sasi customary law model, Sasi Laut only applies to superior strategic commodities of the sea that have high economic value. Thus, the community is free to engage in fishing activities in the Sasi Sea region by the requirement not to use fishing gear that damages sea areas such as fish bombs, cyanide, and fish (electric) stingers. In upholding illegal fishing through customary sasi law, indigenous peoples have a very important role in upholding the implementation of sea sasi, indigenous peoples form customary institutions, namely 1) through the church, 2) Customary parties, in this case represented by soa petuanan authority holders at sea, and 3) Village government.

\section{REFERENCES}

[1] Konsep BPHN ke 2, Research Report about: Penegakan Hukum Di Perairan Indonesia Dan Zona Tambahan, (Jakarta, 14 September 2006) hlm 1

[2] Wilkinson, C. Status of Coral Reefs of the World: 2008. Townsville, Australia: Global Coral Reef Monitoring Network and Reef and Rainforest Research Centre. 2008.

[3] Burke, Selig and Spalding, Reefs at Risk in Southeast Asia. World Resources Institute, 2002.

[4] Kementerian Kelautan dan Perikanan, Laut dan Masyarakat Adat, Jakarta: Kompas, 2017. hlm ix

[5] A. Satria. Politik Kelautan dan Perikanan, Jakarta: Yayasan Pustaka Obor Indonesia, 2016

[6] Zamroni, Pengembangan Pengantar Teori Sosial, Yogyakarta: Tiara Yogya, 1992

[7] B.Z.A. Tamanaha, General Juripnsdence of Law and Society, New Yorl: New York Oxford University Press, 2006

[8] N. Fauzi \& M. Siscawati, Masyarakat Hukum Adat, Yogyakarta: Insist Press, 2014 